\title{
Importance of health literacy for the improvement of paediatric and adult vaccination coverage in Poland
}

\author{
Witold A. Zatoński \\ Health Promotion Foundation, Nadarzyn, Poland \\ European Observatory of Health Inequalities, the President Stanisław Wojciechowski State University of Applied Sciences \\ in Kalisz, Poland
}

ADDRESS FOR CORRESPONDENCE: Witold A. Zatoński, Health Promotion Foundation, 51 Mszczonowska Street, 05-830 Nadarzyn, Poland, phone: +48 2237800 22, e-mail: wazatonski@promocjazdrowia.pl

After the Second World War (WWII), infectious disease control became one of the most important public health priorities in Poland. Due to the widespread nature of communicable disease (predominantly tuberculosis), life expectancy after WWII stood at approximately 50 years in the Polish population. In 1950 over $30 \%$ of new-born children in Poland did not live past the age of 5. In 1959, infectious disease mortality in Poland $(97 / 100,000)$ was ten times higher than in Sweden $(10 / 100,000)[1-4]$.

This problem was tackled with incredible effectiveness and speed in less than two decades. For example, in 1959 Poland became one of the first countries in the world to introduce mass polio vaccination. In the $1960 \mathrm{~s}$ polio morbidity decreased from a few thousand cases to several cases per year [5]. In Poland, introducing obligatory vaccination of children has lad to a revolutionary decrease in their mortality. Mortality in children under the age of 5, which amounted to $30 \%$ in 1950, dropped to approximately $2.5 \%$ in 1990, and in 2017 it was approximately $0.5 \%$. Similar progress was made in the fight against many other communicable diseases. By the 1970s, infectious diseases were no longer a public health priority in Poland, and life expectancy for adults, as well as child mortality, was comparable to Western Germany or the UK [4-6].

Unfortunately, in the last decade the system of infectious disease prevention in Poland has been under severe strain. The proliferation of anti-vaccination content on the internet, combined with co-ordinated misinformation activity conducted by so-called 'Russian trolls' (a worrying trend that warrants further research) [7], meant that the immunisation rate against measles in Poland, which stood at almost $100 \%$ at the break of the $21^{\text {st }}$ century, declined rapidly. Vaccination-related health illiteracy has made a return to Poland, and we are starting to see its biological impact. In recent years we have witnessed first deaths from measles (Figure 1). However, this problem is not limited to Poland. In many other EU countries, a similar worrying trend has been observed. Restoring high levels of vaccination coverage, which would be economically and socially optimal, should be a Europe-wide public health priority.

In the last two decades numerous highly effective vaccines have been introduced worldwide. This has been accompanied by a number of 'natural experiments' on a population scale - two examples of which took place in Poland. The first was related to the introduction and proliferation (including increased availability and affordability) of the Hepatitis B vaccine in the 1990s. Although the vaccine is not mandatory, and is not publicly funded for the majority of the population, the uptake of the Hepatitis B vaccine grew rapidly. In less than 10 years from its introduction Poland has witnessed a significant decline in Hepatitis B morbidity [8].

The second 'natural experiment', tackled by several articles in this issue of the JHI, is a negative one and is related to the poor coverage of influenza vaccination, which in Poland stands at just a few percent every season [8]. We are pleased to present to our readers an economic analysis of the losses caused by poor influenza immunisation rates in Poland, alongside commentaries from British and Italian experts [9-11]. They explore the stark contrast between rates in Poland, and in the UK and Ita- 


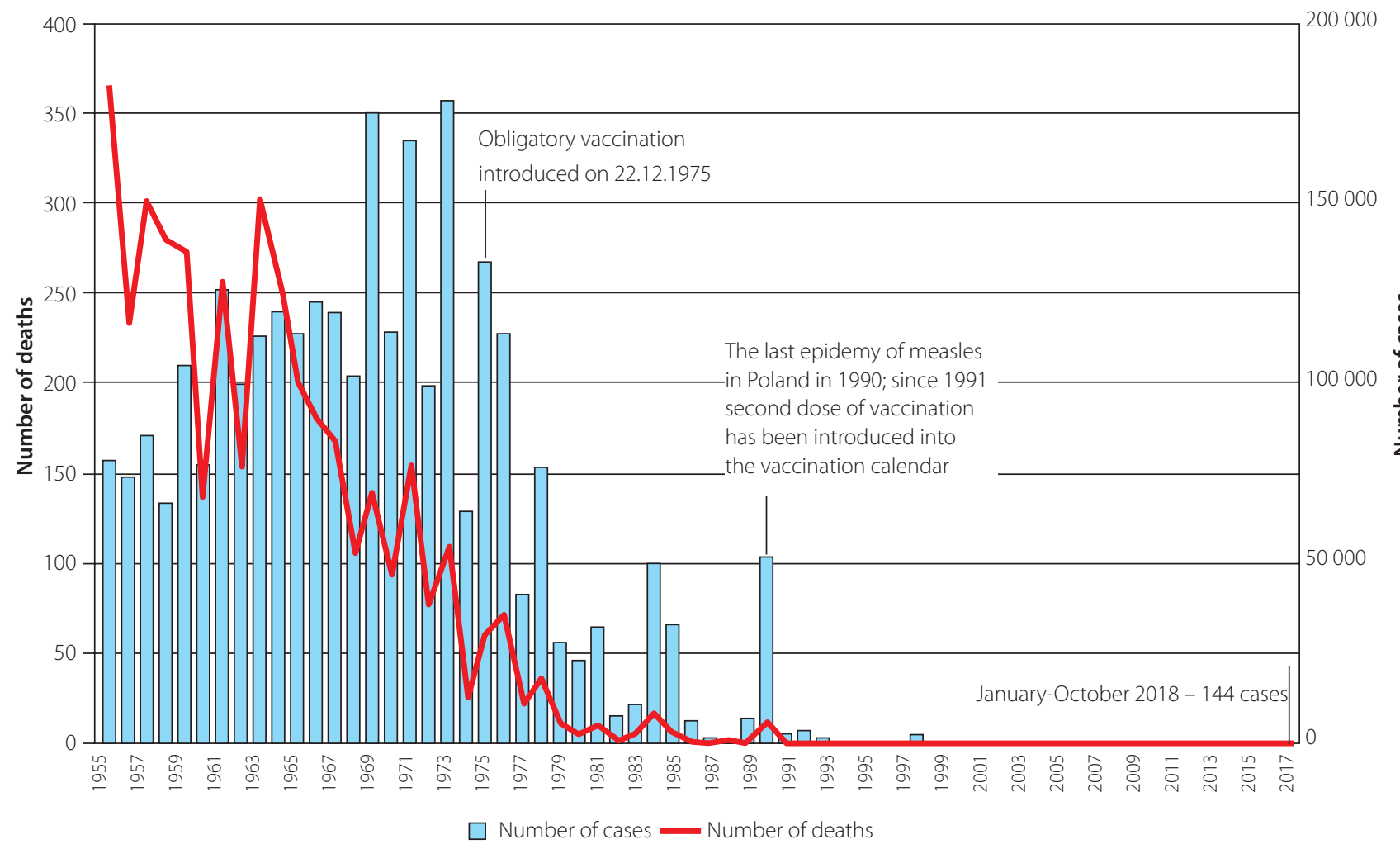

Source: Chief Sanitary Inspectorate; on the basis of infographic by Danuta Pawłowska, BIQdata.wyborcza.pl

FIG. 1. Measles, number of cases in Poland

ly, where well above half of the eligible population gets protected from influenza every year $[9,11]$.

The picture that emerges from this issue is that of the propagation of influenza vaccination as one of the most pressing (and at the same time a relatively simple and cheap to solve) public health interventions to be implemented in Poland as soon as possible. The Polish government and society strive to achieve a straightforward measurable target - matching the influenza immunisation rates in countries like the UK and Italy by the end of 2024.

\section{DISCLOSURE}

The author reports no conflict of interest.

\section{References}

1. Holzer JZ. Demografia [Demography]. Rocznik Statystyczny [Statistical Year]. Warszawa 1955; 57.

2. Zatoński WA, Zatoński M. Health in the Polish People’s Republic. J Health Inequal 2016; 2: 7-16.

3. Zatoński WA, Zatoński M. Sytuacja zdrowotna [Health situation]. In: Dzieje medycyny w Polsce, tom 3. Lata 1944-1989 [History of medicine in Poland, volume 3. For the years 1944-1989].
Noszczyk W (ed.). Wydawnictwo Lekarskie PZWL, Warszawa 2016; 77-86.

4. Mackenbach JP, Looman CW. Life expectancy and national income in Europe, 1900-2008: an update of Preston's analysis. Int J Epidemiol 2013; 42: 1100-1110.

5. Williams G. Paralysed with fear: the story of Polio. Palgrave Macmillan UK, London 2013; 218-247.

6. Zatoński WA, Zatoński M. Democracy is healthier - health in Poland in the late 1980s and 1990s. J Health Inequal 2016; 2: 17-24.

7. Broniatowski DA, Jamison AM, Qi S, et al. Weaponized health communication: twitter bots and Russian trolls amplify the vaccine debate. Am J Public Health 2018; 108: 1378-1384.

8. Wojtyniak B, Goryński P (eds.). Health status of Polish population and its determinants - in short. National Institute of Public Health - National Institute of Hygiene, Warsaw 2018; 63.

9. Zatonski MD. Influenza vaccination in Poland - it's time to close the health gap! J Health Inequal 2018; 4: 81-82.

10. Seweryn M. Potential savings resulting from avoided hospitalizations and avoided productivity losses due to low influenza vaccination coverage in Poland. J Health Inequal 2018; 4: 74-78.

11. de Waure Ch. Influenza vaccination in Italy: current scenario and critical issues. J Health Inequal 2018; 4: 83-84. 